\title{
Sularda, İnsan Enfeksiyonları ile İlişkili Norovirus Genogruplarının Real- Time PCR Yöntemi ile Saptanması
}

\author{
Mehmet Demirci ${ }^{1}$, Akın Yiğin², Nadire Eser ${ }^{3}$, Hikmet Dinç ${ }^{4}$ \\ ${ }^{1}$ Beykent Üniversitesi, Tip Fakültesi, Tıbbi Mikrobiyoloji Anabilim Dalı, İstanbul Türkiye. \\ ${ }^{2}$ Harran Üniversitesi, Veteriner Fakültesi, Genetik Anabilim Dall, Şanluurfa, Türkiye \\ ${ }^{3}$ Kahramanmaraş Sütçü imam üniversitesi Tıp Fakültesi Tıbbi Farmakoloji Anabilim Dalı Kahramanmaraş, Türkiye \\ ${ }^{4}$ Harran Üniversitesi Veteriner Fakültesi, Farmakoloji Anabilim Dalı, Şanlıurfa, Türkiye
}

Geliş Tarihi / Received: 09.10.2018, Kabul Tarihi / Accepted: 11.11.2018

\begin{abstract}
Özet: İnsan norovirüsü (HNoV), çevresel etkenlere oldukça dirençli bir RNA virüsüdür ve akut viral gastroenteritin nedeni olan ana etkenlerden birisidir. Hızlı evrim yeteneği nedeniyle 7 genogrubu vardır ve bunlardan GI, GII ve GIV insan enfeksiyonları ile ilişkilidir. Sular $\mathrm{HNoV}$ için salgın aracı olarak tanımlamaktadır. Bu bilgiler 1şı̆̆ında, çalışmamızda, lokal kuyular ve derelerden alınan su numunelerinde özellikle insanlarda enfeksiyonları ile ilişkili HNoV genogrup (G)I, GII ve GIV varlığının gerçek zamanlı polimeraz zincir reaksiyonu (real-time PCR) ile tanımlanarak moleküler epidemiyolojik bir veri sağlanması amaçlanmıştır.
\end{abstract}

Çalışma için lokal kuyulardan ve derelerden, Ocak 2017 - Ocak 2018 döneminde toplanan 60 adet su numunesi çalışmamıza dahil edildi. RNA izolasyonu ve cDNA sentezi sonrası HNoV GI, GII ve GIV spesifik primer problar ile LightCycler 480 sisteminde real-time PCR yöntemi ile çalışıldı ve sonuçlar değerlendirildi.

Çalışmamıza dâhil edilen 60 numunede, HNoV GII'nin \%10 düzeyinde saptandığı, bunu sırasıly GI (\%5) ve GIV (\%1.67) varlığının takip ettiği tespit edildi. 10 numunede (\%16.67) HNoV GI, GII ve GIV pozitifliği bulundu. Lokal kuyulardan 3 (\%8.57) tanesinde ve derelerden alınan numunelerden de 7 (\%28) tanesinde pozitiflik saptand1.

Sonuç olarak, ülkemizde ilk defa kuyu suları ve derelerden alınan sularla yaptığımız çalışmamızla, moleküler epidemiyolojik olarak HNoV varlığını saptadık. HNoV'lar arasında GII'nin ön planda tutulması gerektiğini ama GI ve GIV'ünde bulunduğunu tespit ettik. HNoV için salgınlarında sular göz önünde bulundurulmalı ve gelişen moleküler tekniklerle, sular gibi önemli enfeksiyon kaynaklarından epidemiyolojik veriler sağlanarak durum ortaya konabilir ve bu bilgiler ile bölgesel aşı geliştirme çalışmaları içinde ön veriler sağlanabileceği kanaatindeyiz.

Anahtar Kelimeler: Su, real-time PCR, Norovirüs genogrupları

\section{Determination of Norovirus Genogroups Associated with Human İnfections in Water by Real-Time PCR Method}

\begin{abstract}
Human norovirus ( $\mathrm{HNoV})$ is a RNA virus that is highly resistant to environmental conditions and is one of the main causes of acute viral gastroenteritis. It has 7 genogroups, due to ability of rapid evolution, and which genogrup (G)I, GII and GIV are associated with human infections. The waters describe HNoV as an epidemic source. Aim of this study was to provide molecular epidemiological data by using real-time polymerase chain reaction (real-time PCR) of HNoV GI, GII and GIV presence related to infections in water samples taken from local underground waters and creeks.

Sixty (60) water samples collected from local underground waters and creeks, between January 2017 and January 2018 , were included in our study. After RNA isolation and cDNA synthesis, HNoV GI, GII and GIV specific primary and probes were used on LightCycler 480 system by real-time PCR method and the results were evaluated.

In the 60 samples included in our study, it was found that HNoV GII was detected at $10 \%$ level, followed by GI (5\%) and GIV (1.67\%) respectively. HNoV GI, GII and GIV positivity were found in 10 samples (16.67\%). 3 (8.57\%) of the local underground waters and 7 (28\%) of the creeks water samples were found positive.

As a result, we determined the presence of $\mathrm{HNoV}$ by molecular epidemiology in our country for the first time in our study with water taken from underground waters and creeks. We found that GII should be in the forefront of HNoVs, but it was found in GI and GIV. For HNoV, water should be considered in outbreaks, and epidemiological data can be obtained from important sources of infection, such as water, by developing molecular techniques, and we believe that data in this study can be important epidemiologically and can be used for regional vaccine development studies.
\end{abstract}

Key words: Water, real-time PCR, Norovirüs genogroups 


\section{Giriş}

İnsan norovirüsü (HNoV), Calicidiviridea ailesi içinde bulunan pozitif polariteli bir RNA virüsüdür ve akut viral gastroenteritin nedeni olan ana etkenlerden birisidir [12]. Çevresel etkenlere oldukça dirençli olan $\mathrm{HNoV}$, dünya çapında sporadik ve epidemik bakteriyel olmayan (viral) gastroenteritlere neden olur (15). HNoV esas olarak fekal-oral yoldan yayılır. Bulaşması, doğrudan (kişiden kişiye geçişle), dolaylı (kontamine ürünlere temas yoluyla) ve kontamine yiyecek veya suların sindirimi yoluyla olabilir [17]. Hizlı moleküler evrim yeteneği nedeniyle, virüsün yeni genotipleri ve varyantları s1klıkla bildirilmektedir. Hatta nükleik asitinde bu hızlı değişim yeteneği nedeniyle fantastik bir canavara ("șekil değiștiren") benzetilmektedir. Şu ana kadar viral protein genomu (VP1) aminoasit dizisinin incelenmesi ile 7 genogrup ([G]I - GVII) ve 40'ın üzerinde norovirüs genotipi tanımlanmıştır [19]. Bunlardan üçü GI, GII ve GIV insanlarda hastalığa neden olabilir [1]. GII genogrup, klinik vakalarda GI'den daha sık saptanırken, GIV'ün daha nadir vakalarda tespit edildiği bildirilmiștir [10]. GII.4 dünya çapında en yaygın olan genotiptir ve 1990'ların ortasından beri moleküler tanı tekniklerinin, aktif sürveyans için kullanımının başlamasından beri, pek çok küresel salgınla ilişkilendirilmiştir [19]. Norovirüs enfeksiyonları, 12-48 saat inkübasyon süresine sahiptir ve semptomlar tipik olarak bulant1, kusma, ishal, karın ağrısı ve ateşi içerir. Norovirüs enfeksiyonları genellikle hafif ve orta semptomlarla kendini sınırlandırır, ancak immün sistemi bask1lanmış hastalarda ve yaşlılarda ciddi enfeksiyonlar görülebilir. Semptomlar genellikle 1-3 gün sürer, ancak genç, yaşlı ve bağışıklık sistemi baskılanmış hastalarda daha uzun sürebilir [5]. İlk defa 1980 yılında küçük bir kasabada su kaynaklı norovirus salgını olduğu rapor edilmiştir [8] ve bu bilgi sonras1 epidemiyolojik veriler bu etkenin suları salgın aracı olarak kullandığını tanımlamıştır. Özellikle, su kaynaklı, büyük ölçekli salgınlarda norovirüs türleri saptandığında, içme sularının, insan dışkı kaynağı tarafindan kontaminasyonu da düşünülmelidir [6]. HNoV'un genotipik değişkenliği nedeniyle yap1lacak olan moleküler epidemiyolojik çalıșmalar, salgınlarda gözlemlenebilecek durumu açıklaması açısından ve ayrıca aşı çalışmaları içinde önemli bir veri sağlamaktadır [19]. Bunun yanında bulaşık sulların kullanılması ağır metal toksikasyonu ya da bakteriyel kaynaklı gastroinstistinal enfeksiyonlar ile karışabildiği için bu virüsün durumunun ortaya konmas1 önemli hale gelmektedir. Tüm bu bilgiler ışığında, çalışmamızda, lokal kuyular ve derelerden alınan su numunelerinde özellikle insanlarda enfeksiyonlar ile ilişkili HNoV genogrup (G)I, GII ve GIV varlığının gerçek zamanlı polimeraz zincir reaksiyonu (real-time PCR) ile tanımlanarak moleküler epidemiyolojik bir veri sağlanması amaçlanmiștır.

\section{Materyal ve Metot}

Çalışma için Mardin, Gaziantep, Şanlıurfa ve Kahramanmaraş il, ilçe ve köylerinde bulunan lokal kuyulardan ve derelerden, Ocak 2017 - Ocak 2018 döneminde $5 \mathrm{ml}$ olarak steril plastik kaplara toplanan 60 adet su numunesi çalışmamıza dahil edildi. Numuneler soğuk zincir koşullarında hızlıca laboratuvara transfer edildi ve RNA izolasyonları 24 saat içinde tamamlandı. Schultz ve ark. [18], 2010 yılında tanımladıkları protokol izlenerek, su numunelerinden RNA izolasyonu için ultrafilitrasyonla numuneler işleme alındı. Ultrafilitrasyon sonrası bu numunelerin 200 mikrolitre miktarları ile, QIAamp Viral RNA Mini kit (Qiagen, Hilden, Almanya) kullanılarak üretici direktifleri doğrultusunda RNA izolasyonları gerçekleştirildi. RNA'lar, komplementer DNA (cDNA) sentezi işlemlerine kadar $-80^{\circ} \mathrm{C}$ ' de sakland1. cDNA'lar First Strand cDNA synthesis kit (Roche Diagnostics, Mannheim, Almanya) kullan1larak üretici direktifleri doğrultusunda olușturuldu. cDNA'lar real-time PCR aşamasına kadar $-20^{\circ} \mathrm{C}^{\prime} \mathrm{de}$ sakland1. İnsanlarda enfeksiyonlarla ilişkili olan HNoV GI, GII ve GIV genogruplarını saptayabilmek için Tablo 1'de verilen spesifik primer ve problar kullanıldı $[3,16]$. RNA izolasyonlarının doğruluğunu kontrol etmek için çalıșmada RNA process control kit (Roche Diagnostics, Mannheim, Almanya) üretici direktifleri doğrultusunda kullanıldı.

cDNA'lar, primer ve probla birlikte, LightCycler 480 Probe Master kit (Roche Diagnostics, Mannheim, Almanya) üretici direktifleri doğrultusunda kullanılarak, real-time PCR işlemleri, LightCycler 480 sisteminde gerçekleştirildi. Her bir reaksiyonda 5 ul cDNA kullanıldı ve PCR profili başlangıç akti- 
vasyon aşaması olarak; $95^{\circ} \mathrm{C}^{\prime}$ de 10 dakika, takiben 45 siklus, denaturasyon, uzama ve çoğaltma aşama-
S1 olarak sirasiyla $95^{\circ} \mathrm{C}^{\prime}$ de $10 \mathrm{sn}, 60^{\circ} \mathrm{C}$ 'de 30 sn ve $72^{\circ} \mathrm{C}^{\prime}$ de 1 sn şeklinde gerçekleştirildi.

Tablo 1: Genogrup I, GII ve GIV saptanması için real-time PCR'da kullanılan primer dizileri

\begin{tabular}{lllc}
\hline Genogrup & Primer Adı & Oligonukleotid dizisi (5'>3') & Referans \\
\hline GI & QNIF4 & CGCTGGATGCGNTTCCAT & 11 \\
& NV1LCR & CCTTAGACGCCATCATCATTTAC & 11 \\
\hline GII & NV1LCpr & FAM- TGGACAGGAGAYCGCRATCT-TAMRA & 11 \\
& QNIF2d & ATGTTCAGRTGGATGAGRTTCTCWGA & 11 \\
& COG2R & TCGACGCCATCTTCATTCACA & 11 \\
GIV & QNIFS & FAM- AGCACGTGGGAGGGGATCG-TAMRA & 11 \\
\hline & NIFG4F & ATGTACAAGTGGATGCGRTTC & 12 \\
& COG2R & TCGACGCCATCTTCATTCACA & 12 \\
\hline
\end{tabular}

\section{Bulgular}

Çalışmamıza dahil edilen 60 numunede saptanan genogrupların dağılımı Tablo 2'de verilmiştir. 60 numuneden, 10 tanesinde (\%16.67) HNoV GI, GII ve GIV pozitifliği bulundu. Lokal kuyulardan 3
(\%8.57) tanesinde ve derelerden alınan numunelerden de 7 (\%28) tanesinde pozitiflik saptand. HNoV genogrupları incelendiğinde, $6(\% 10)$ numunede GII, $3(\% 5)$ numunede GI ve $1(\% 1.67)$ numunede GIV olduğu saptandi.

Tablo 2: Genogrupların dağılımı

\begin{tabular}{|c|c|c|c|c|}
\hline \multicolumn{5}{|c|}{ Norovirüs Genogrup } \\
\hline & GI & GII & GIV & Toplam \\
\hline Lokal Kuyular n:35 & $1(2.86)$ & $2(5.71)$ & $0(0)$ & $3(8.57)$ \\
\hline Dereler n:25 & $2(8.00)$ & $4(16.00)$ & $1(4.00)$ & $7(28.00)$ \\
\hline Toplam: 60 & $3(5.00)$ & $6(10.00)$ & $1(1.67)$ & $10(16.67)$ \\
\hline
\end{tabular}

Derelerden alınan sularda özellikle GII \%16 olarak en yüksek düzeyde saptanırken, derelerden alınan sularda GI, GII ve GIV pozitifliği \%28 oranında bulundu. Lokal kuyularda ise GI \%2.86 ve GII \%5.71 oranında saptanırken, GIV pozitifliği bulunmadi. GIV sadece 1 numunede derelerden alınan numuneler arasindan saptandi. Derelerde, kuyulardan alınan numunelere göre daha yüksek sayıda HNoV pozitifliği saptandığ
Tüm numunelerde durum incelendiğinde, $\mathrm{Nu}$ munelerde, HNoV GII'nin \%10 düzeyinde saptandığı, bunu sirasıyla GI (\%5) ve GIV (\%1.67) varl1ğının takip ettiği tespit edildi.

Pozitiflik saptanan sularda Norovirüs ve genogrupların dağılımı incelendiğinde, Ocak aylarında en yüksek pozitiflik saptandığı, bunu Şubat ayının izlediği görülmektedir (Tablo 3). 
Tablo 3: Norovirüs ve genogruplarının mevsimsel dağ1$\underline{\lim 1}$

\begin{tabular}{lcccc}
\hline Ay & \multicolumn{4}{c}{ Norovirüs } \\
\hline & GI & GII & GIV & Toplam \\
Ocak 17 & 1 & 1 & 0 & 2 \\
Şubat 17 & 1 & 1 & 0 & 2 \\
Mart 17 & 0 & 0 & 0 & 0 \\
Nisan 17 & 0 & 0 & 0 & 0 \\
May1s 17 & 0 & 0 & 0 & 0 \\
Haziran 17 & 0 & 0 & 0 & 0 \\
Temmuz 17 & 0 & 0 & 0 & 0 \\
Ağustos 17 & 0 & 0 & 0 & 0 \\
Eylül 17 & 0 & 1 & 0 & 1 \\
Ekim 17 & 0 & 1 & 0 & 1 \\
Kasım 17 & 0 & 1 & 0 & 1 \\
Aralık 17 & 1 & 0 & 0 & 1 \\
Ocak 18 & 0 & 1 & 1 & 2 \\
Toplam & 3 & 6 & 1 & 10 \\
\hline
\end{tabular}

\section{Tartışma ve Sonuç}

Su kaynaklı virüslerin saptanması, özellikle içilebilir suyun az olduğu yerlerde halk sağlığı açısından önemlidir. Su kaynaklı enfeksiyonlarda norovirüs yaygın olarak bildirilmektedir. Doğası gereği, bu kontaminasyon sıklıkla biyolojik atıklarla ilişkilidir [4]. Çevre koşullarında uzun süre yaşama şansı olduğu için bu Norovirüslerin önemini arttırmaktadır [9]. Yenilenme yeteneği hızlı olan ve farklı pek çok genogrup, genotip ve varyantları bulunan norovirüslerin moleküler epidemiyolojik olarak sularda incelenerek durumunun bilinmesi, hem epidemiyolojik veri sunması, hem de ulusal aşı çalışmalarında da kullanılabilmesi açısından değerlidir [4].

Uluslararası çalışmalar incelendiğinde; Kuyular gibi yer altı sularında yapılan çalışmalarda, Joung ve ark, 2013 y1lında, Güney Kore'de yer altı sularında sadece $\% 0.5$ oranında GII pozitifliği saptamışlardır [7]. Lee ve ark, 2013 yılında Güney Kore'de yaptıkları çalışmada yer altı sularını incelediklerinde, $\mathrm{HNoV}$ için \%0.64 pozitiflik saptamışlar ve bu pozitif numunelerden sadece 1 tanesinde GI, 6 tanesinde GII olduğunu bildirmişlerdir [13]. Bizde çalışmamızda kuyu numunelerimizden sadece 3 tanesinde pozitiflik saptadık, verilen oranlara benzer şekilde kuyu numunelerinde dere gibi kontaminasyona daha açık numunelere göre daha düşük se- viyede $\mathrm{HNoV}$ varlığı olduğu anlaşılmaktadır. Tüm çalışmalarda GII varlığının bizim çalışmamızdakine benzer şekilde yüksek olduğu görülmektedir.

Yine uluslararası çalışmalarda, derelerdeki durum incelendiğinde, Aw ve ark, 2009 yılında Singapur'da derelerde yaptıkları çalışmalarında 60 numuneden 4 tanesinde (\%9.3) GI, 16 tanesinde (\%37.2) GII ve 23 tanesinde (\%53.5) GI ve GII birlikteliği olmak üzere toplam $43(\% 71.7) \mathrm{HNoV}$ pozitifliği bildirmişlerdir (2). Lodder ve ark, 2005 yılında Hollanda'da yaptıkları çalışmalarında derelerde 7 pozitiflik saptamışlar ve bunların 2 tanesini GI ve 5 tanesini GII olarak tespit etmişlerdir [14]. Kim ve ark, 2016 yılında Güney Kore'de yaptıkları çalışmalarında, GI için \%13.3 ve GII için \%16.6 pozitiflik bildirmişlerdir [11]. Vantarakis ve ark, 2011 yılında Yunanistan'da yaptıkları çalışmalarında derelerden ald1kları su numunelerinde, \%56.8 oranında HNoV bildirmişler ve bunların tamamının GII olduğunu rapor etmişlerdir [21]. Dere gibi biyolojik kontaminasyona kuyulara göre daha açık sularda HNoV kontaminasyonunun daha yüksek seviyelerde olduğu ve ülkeden ülkeye hatta bölgeden bölgeye değişiklik gösterdiği görülmektedir. Bizim çalışmamızda saptadığımız \%28'lik pozitifliğin bu anlamda çalışmalarla benzerlik gösterdiğini söyleyebiliriz. Ayrıca çalışmamızdakine benzer şekilde GII varlığı, diğer genogruplara göre ağırlık göstermektedir.

Ülkemizde yapılan çalışmalar incelendiğinde, sıklıkla salgınlarla ilişkili olarak dışkı numunelerinden incelemeler yapıldığ 1 ve literatürde bizim çalışmamıza benzer şekilde sular ile yapılmış bir çalışmaya rastlamadık. Her ne kadar aynı numune üzerinden olmasada Timurkan ve ark [20], dışk1 numunelerinde yaptıkları çalışmalarında, GII'yi en yüksek düzeyde saptadıklarını, 1'er numunede de GI ve GIV varlığı bulduklarını bildirmişlerdir. $\mathrm{Bu}$ veride, yine çalışmamız verilerine benzer şekilde GII varlığının ülkemizde diğer ülkelerdekine de benzer şekilde yüksek olduğunu ama GI ve GIV'ünde olabileceğini bize düşündürmüştür.

Norovirüs genotiplerinin mevsimsel dağılımının incelendiği çalışmalara bakıldığında, Kim ve ark [11], Güney Kore'de sularda saptadıkları Norovirüs pozitifliklerini bizim çalışmamızdakine benzer şekilde kış aylarında arttığını bildirmişlerdir. Delgado-Gardea ve ark [4] 2017 y1lında Meksika'da yap- 
tıkları çalışmada, sularda Ekim ayında daha yüksek konsantrasyonda Norovirüs pozitifliği saptadıklarını bildirmişlerdir. Jalava ve ark [6], 2014 yılında Finlandiya' daki salgınlar sırasında suları incelediklerinde Temmuz ayında sularda Norovirüs pozitifliği saptamışlardır. Ülkemiz ve Finlandiya arasında 1S1 farklılı̆̆1 göz önüne alındığında, 1S1 farklılığının çalışmamız sonuçlarına göre fark yarattığını bize düşündürmüştür. Kauppinen ve Miettinen [9], 2017 yılında yaptıkları çalışmada bu düşüncemizi desteklemişlerdir. $3^{\circ} \mathrm{C}, 21^{\circ} \mathrm{C}$ ve $36^{\circ} \mathrm{C}$ ' da sularda Norovirüs kantitatif durumunu incelediklerinde $36^{\circ} \mathrm{C}$ ' da Norovirüs kantitatif miktarların en düşük seviyede olduğunu ve 1sı artışı ile düşüş gösterdiğini bildirmişlerdir. İncelediğimiz çalışmalardaki Norovirüs'ün mevsimsel dağılımı sonuçları çalışmalarımız sonuçları ile benzer saptanmıştır.

Sonuç olarak, ülkemizde ilk defa kuyu suları ve derelerden alınan sularla yaptığımız çalışmamızla, moleküler epidemiyolojik olarak HNoV varlığının sularımızda olabileceğini, derelerde, kuyu sular1na göre kirliliğin daha fazla düzeyde olabileceğini saptadık. HNoV'lar arasında GII'nin ön planda tutulması gerektiği ama GI ve GIV'ünde varlığının olduğunu gözlemledik. Halk sağlığ1 problemi oluşturmaması açısından, HNoV salgınlarında sular göz önünde bulundurulmalı ve yeni moleküler tekniklerle sular gibi önemli enfeksiyon kaynaklarından epidemiyolojik veriler elde edilerek durum ortaya konabilir ve bu bilgiler ile bölgesel aşı geliştirme çalışmaları içinde ön veriler sağlanabileceği kanaatindeyiz.

\section{Kaynaklar}

1. Atmar RL, (2010). Noroviruses - State of the Art. Food and environmental virology. 2(3), 117-126. doi:10.1007/ s12560-010-9038-1.

2. Aw TG, Gin KY-H, Ean Oon LL, Chen EX, Woo CH, (2009). Prevalence and Genotypes of Human Noroviruses in Tropical Urban Surface Waters and Clinical Samples in Singapore. Applied and Environmental Microbiology. 75(15), 4984-4992. doi:10.1128/AEM.00489-09.

3. Da Silva AK, Le Saux J-C, Parnaudeau S, Pommepuy M, Elimelech M, Le Guyader FS, (2007). Evaluation of Removal of Noroviruses during Wastewater Treatment, Using Real-Time Reverse Transcription-PCR: Different Behaviors of Genogroups I and II. Applied and Environmental Microbiology. 73(24), 7891-7897. doi:10.1128/AEM.01428-07.
4. Delgado-Gardea MCE, Tamez-Guerra P, Gomez-Flores R, Mendieta-Mendoza A, Zavala-Díaz de la Serna FJ, Contreras-Cordero JF, Erosa-de la Vega G, Pérez-Recoder MC, Sánchez-Ramírez B, González-Horta C, InfanteRamírez R, (2017). Prevalence of Rotavirus Genogroup $A$ and Norovirus Genogroup II in Bassaseachic Falls National Park Surface Waters in Chihuahua, Mexico. International Journal of Environmental Research and Public Health.14(5), 482. doi:10.3390/ijerph14050482.

5. Huang X-Y, Su J, Lu Q-C, Li SZ, Zhao JY, Li ML, Li Y, Shen X-J, Zhang B-F, Wang H-F, Mu Y-J, Wu S-Y, Du Y-H, Liu L-C, Chen W-J, Klena JD, Xu B-L, (2017). A large outbreak of acute gastroenteritis caused by the human norovirus GII.17 strain at a university in Henan Province, China. Infectious Diseases of Poverty. 6, 6. doi:10.1186/ s40249-017-0236-z.

6. Jalava K, Rintala H, Ollgren J, Maunula L, Gomez-Alvarez V, Revez J, Palander M, Antikainen J, Kauppinen A, Räsänen P, Siponen S, Nyholm O, Kyyhkynen A, Hakkarainen S, Merentie J, Pärnänen M, Loginov R, Ryu H, Kuusi M, Siitonen A, Miettinen I, Santo Domingo JW, Hänninen M-L \& Pitkänen T, (2014). Novel Microbiological and Spatial Statistical Methods to Improve Strength of Epidemiological Evidence in a Community-Wide Waterborne Outbreak. PLoS ONE. 9(8), e104713. doi:10.1371/journal.pone.0104713.

7. Joung HK, Han SH, Park S-J, Jheong WH, Ahn TS, Lee JB, Jeong Y-S, Jang KL, Lee G-C, Rhee O-J, Park J-W, Paik SY, (2013). Nationwide Surveillance for Pathogenic Microorganisms in Groundwater near Carcass Burials Constructed in South Korea in 2010. International Journal of Environmental Research and Public Health. 10(12), 7126-7143. doi:10.3390/ijerph10127126.

8. Kaplan JE, Goodman RA, Schonberger LB, Lippy EC, Gary GW, (1982). Gastroenteritis due to Norwalk virus: an outbreak associated with a municipal water system. J Infect Dis. 146(2), 190-197.

9. Kauppinen A, Miettinen IT, (2017). Persistence of Norovirus GII Genome in Drinking Water and Wastewater at Different Temperatures. Pathogens. 6(4), 48. doi:10.3390/ pathogens6040048.

10. Kazama S, Miura T, Masago Y, Konta Y, Tohma K, Manaka T, Liu X, Nakayama D, Tanno T, Saito M, Oshitani H, Omura T, (2017). Environmental Surveillance of Norovirus Genogroups I and II for Sensitive Detection of Epidemic Variants. Applied and Environmental Microbiology. 83(9), e03406-16. doi:10.1128/AEM.03406-16.

11. Kim MS, Koo ES, Choi YS, Kim JY, Yoo CH, Yoon HJ, Kim T-O, Choi HB, Kim JH, Choi JD, Park K-S, Shin Y, Kim Y-M, Ko GP, Jeong YS, (2016). Distribution of Human Norovirus in the Coastal Waters of South Korea. PLoS ONE. 11(9),e0163800. doi:10.1371/journal.pone.0163800.

12. Koo ES, Kim MS, Choi YS, Park K-S, Jeong YS. (2017) Occurrence of novel GII.17 and GII.21 norovirus variants in the coastal environment of South Korea in 2015. PLoS ONE. 12(2), e0172237. doi:10.1371/journal.pone.0172237.

13. Lee B-R, Lee S-G, Park J-H, Kim KY, Ryu SR, Rhee OJ, Park J-W, Lee J-S, Paik S-Y, (2013). Norovirus Contamination Levels in Ground Water Treatment Systems 
Used for Food-Catering Facilities in South Korea. Viruses. 5(7), 1646-1654. doi:10.3390/v5071646.

14. Lodder WJ, de Roda Husman AM, (2005). Presence of Noroviruses and Other Enteric Viruses in Sewage and Surface Waters in The Netherlands. Applied and Environmental Microbiology. 71(3), 1453-1461. doi:10.1128/AEM.71.3.1453-1461.2005.

15. Masago $Y$, Konta $Y$, Kazama S, Inaba M, Imagawa $T$, Tohma K, Saito M, Suzuki A, Oshitani H, Omura T, (2016). Comparative Evaluation of Real-Time PCR Methods for Human Noroviruses in Wastewater and Human Stool. PLoS ONE. 11(8), e0160825. doi:10.1371/journal.pone.0160825.

16. Miura T, Parnaudeau S, Grodzki M, Okabe S, Atmar RL, Le Guyader FS (2013). Environmental Detection of Genogroup I, II, and IV Noroviruses by Using a Generic Real-Time Reverse Transcription-PCR Assay. Applied and Environmental Microbiology. 79(21), 6585-6592. doi:10.1128/AEM.02112-13.

17. Pouillot R, Van Doren JM, Woods J, Plante D, Smith M, Goblick G, Roberts C, Locas A, Hajen W, Stobo J, (2015). Meta-Analysis of the Reduction of Norovirus and MaleSpecific Coliphage Concentrations in Wastewater Treatment
Plants. Applied and Environmental Microbiology. 81(14), 4669-4681. doi:10.1128/AEM.00509-15.

18. Schultz AC, Perelle S, Di Pasquale S, Kovac K, De Medici D, Fach P, Sommer HM, Hoorfar J, (2011). Collaborative validation of a rapid method for efficient virus concentration in bottled water. Int J Food Microbiol. 1;145 Suppl 1:S15866. doi: 10.1016/j.ijfoodmicro.2010.07.030.

19. Siqueira JAM, Bandeira R da S, Oliveira D de S, dos Santos LFP, Gabbay YB (2017). Genotype diversity and molecular evolution of noroviruses: A 30-year (19822011) comprehensive study with children from Northern Brazil. PLoS ONE. 12(6), e0178909. doi:10.1371/journal. pone. 0178909 .

20. Timurkan MÖ, Aydin H, Aktaş O, (2017). Frequency and molecular characterization of human norovirus in Erzurum, Turkey. Turk J Med Sci. 12;47(3), 960-966. doi: 10.3906/sag-1509-87.

21. Vantarakis A, Mellou K, Spala G, Kokkinos P, Alamanos Y, (2011). A Gastroenteritis Outbreak Caused by Noroviruses in Greece. International Journal of Environmental Research and Public Health. 2011;8(8), 3468-3478. doi:10.3390/ ijerph 8083468 . 